Annals of Warsaw University of Life Sciences - SGGW

Land Reclamation No 41, 2009: 3-9

(Ann. Warsaw Univ. of Life Sci. - SGGW, Land Reclam. 41, 2009)

\title{
Selection of material suitable for permeable reactive barriers in the vicinity of landfills
}

\author{
JOANNA FRONCZYK, KAZIMIERZ GARBULEWSKI \\ Department of Geotechnical Engineering, Warsaw University of Life Sciences - SGGW
}

\begin{abstract}
Selection of material suitable for permeable reactive barriers in the vicinity of landfills. This paper focuses on the criteria proposed for the selection of reactive materials suitable for permeable reactive barriers surrounding waste disposal sites. The criteria were divided into three groups: hydraulic, mechanical and sorption. Hydraulic and sorption criteria are equivalents and complementary to one another in the process of reactive material selection. Only a material that fulfills both criteria should be used. The third criterion - mechanical - that is related to the deformation and strength properties of the reactive material should be considered in designing the technology and evaluation of safety conditions.
\end{abstract}

Key words: permeable reactive barrier, reactive materials, sorption, hydraulic and mechanical criteria.

\section{INTRODUCTION}

Waste products and materials resulting from industrial, commercial, mining, and agricultural operations placed in landfills are generally the most dangerous sources of pollution to the environment. In the case of landfill location in unfavorable conditions, unfulfilling the design recommendations, or damage to the synthetic or clay liners and drainage, a groundwater protection system against the infiltration of contaminants from landfills should be installed. Most systems contain vertical impermeable barriers insulating the contaminated soil under the landfill from its surroundings. However, this method, although limiting the flow of groundwater contaminated by leachates from the landfill, does not reduce, but rather increases the concentration of pollutants directly under the landfill. In addition, the impermeable barrier causes changes in groundwater flow, which is not without significance for the natural environment.

One of the innovative methods of environmental protection introduced in the recent years (Gavaskar et al. 2000, Roehl et al. 2005, Suponik 2004) is the method of permeable reactive barriers - PRB (Fig. 1), which improves the natural attenuation processes. Presently, studies are undertaken to identify a reactive material that is inexpensive, but effectively prevents the migration of leachate from landfills.

Between 2005-2008, investigations carried out in the Department of Geotechnical Engineering, Warsaw University of Life Sciences, allowed to propose criteria for the selection of an optimal reactive material whose general classification is given in Figure 1. Analysis of the test results and numerical calculations has led to the conclusion that sorption and hydraulic criteria are equivalents to one another and complementary in the selection 


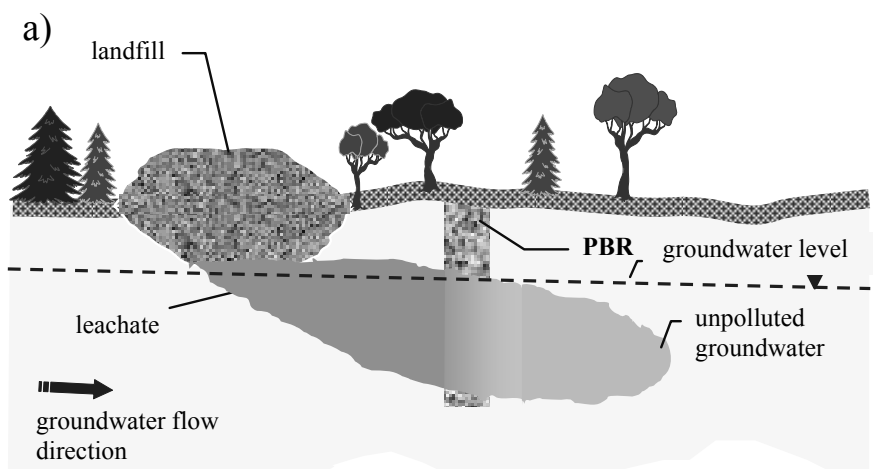

b)

FIGURE 1. The concept of permeable reactive barriers (a) and criteria of reactive material selection (b)

of the material. The third criterion - mechanical properties - related to the compressibility and strength properties, is important with regard to technology and safety conditions. These criteria have been described in this paper in two aspects: geotechnical and environmental requirements.

\section{HYDRAULIC AND MECHANICAL CRITERIA}

The hydraulic criterion in the evaluation of reactive materials such as zeolites and zeolite-sand mixtures is expressed as the ratio of hydraulic conductivity of the reactive material $\left(\mathrm{k}_{\mathrm{s}}\right)$ to the hydraulic conductivity of the aquifer $\left(\mathrm{k}_{\mathrm{g}}\right)$ in the form:

$\frac{\mathrm{k}_{\mathrm{S}}}{\mathrm{k}_{\mathrm{g}}} \geq 10$

Criterion (1) results from the necessity of taking into account changes in the hydraulic properties of materials during PRB exploitation. Laboratory studies showed a decrease of hydraulic conductivity values of zeolite and zeolite-sand mixtures under the influence of landfill leachate (Fronczyk 2008). In the case of zeolite-sand mixtures with a zeolite content $Z$ (dimensionless value), estimation of hydraulic conductivity $\mathrm{k}_{\mathrm{s}}$ in $\mathrm{m} / \mathrm{s}$ at relative density $\mathrm{I}_{\mathrm{D}}$ requires the application of the following equation (Fronczyk 2008):

$$
\mathrm{k}_{\mathrm{S}}=\mathrm{A} \cdot \mathrm{Z} \cdot \mathrm{I}_{\mathrm{D}}{ }^{-0,328}
$$

For mixtures made of zeolite with particle size of $1.0-2.5 \mathrm{~mm}, \mathrm{~A}=3.0$. $\cdot 10^{-4}$, whereas at particle size of $0.5-1.0$ $\mathrm{mm}, \mathrm{A}=2.6 \cdot 10^{-5}$.

In order to control the proper operation of PRB, the term critical hydraulic conductivity $\left(\mathrm{k}_{\mathrm{kr}}\right)$ is introduced, which is defined as the value (decreasing under the influence of the leachate) of the hydraulic conductivity of the aquifer $\left(\mathrm{k}_{\mathrm{s}}=\mathrm{k}_{\mathrm{g}}\right)=\mathrm{k}_{\mathrm{kr}}$. A situation when $\mathrm{k}_{\mathrm{s}} / \mathrm{k}_{\mathrm{g}}<1$ is unacceptable, as it means a change of the direction of groundwater flow and the possibility of flow across the barrier. Changes in the hydraulic conductivity for leachates $(\mathrm{k})$ in relation to the hydraulic conductivity for water $\left(\mathrm{k}_{0}\right)$ depending on the pore volume of flow (PVF) may be determined by using the function: 


$$
\mathrm{k} / \mathrm{k}_{0}=504 \cdot(\mathrm{PVF})^{-2,34}
$$

The time elapsing from the start of the operation of the barriers to reach the value of $\mathrm{k}_{\mathrm{g}}=\mathrm{k}_{\mathrm{s}}$ is termed the time of correct functioning of the barrier $t_{\mathrm{PBR}}$. Both $\mathrm{k}_{\mathrm{kr}}$ and $\mathrm{t}_{\mathrm{PRB}}$ depend on local hydrogeological conditions of infiltration into the PRB.

After this time, regeneration of the reactive material is needed to dissolve inorganic compounds, mainly $\mathrm{CaCO}_{3}$, before the creation of solids (VanGulck and Rowe 2004). The condition of the necessity for the regeneration of the reactive material can be described as follows:

$$
\mathrm{k}_{\mathrm{s}}=\alpha_{\mathrm{k}} \cdot \mathrm{k}_{\mathrm{kr}}
$$

where: $\alpha_{k}-$ safety factor.

The safety factor incorporates the uncertainties of calculations and measurements, as well as unforeseen events, such as the heterogeneous nature of the aquifer. According to the authors, based on experience gained from laboratory investigations the value of $\alpha_{\mathrm{k}}=2$ should be adopted.

From these prerequisites it can be concluded that the choice of the reactive material for PRB requires determining the hydraulic conductivity of reactive materials with regard to the relative density and strain conditions in the barrier. In addition, it is necessary to carry out "compatibility tests", i.e. test of contaminated groundwater influence on changes of the hydraulic properties of the selected material. Due to the character of these studies, it is necessary to use equipment made from materials not reacting with contaminated groundwater. The analysis, the results of which was the basis of the criteria presented in this paper, was carried out in the apparatus shown in Figure 2.

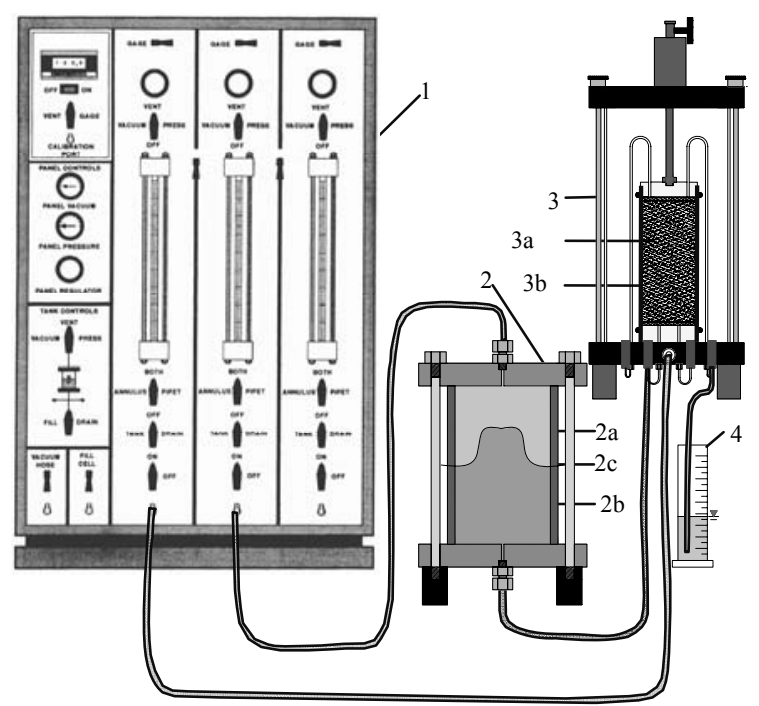

FIGURE 2. Scheme of a flexible-wall perameter: 1 - control panel, 2 - bladder accumulator, $2 \mathrm{a}$ - water, $2 \mathrm{~b}$ - liquid other than water, $2 \mathrm{c}$ - elastic membrane, 3 - chamber, $3 \mathrm{a}$ - sample, $3 \mathrm{~b}$ - latex membrane, 4 - measuring cylinder (acc. to Trautwein Soil Testing Equipment Co.) 
Selection of the reactive material from the geotechnical point of view requires the knowledge of the strength and compressibility characteristics of reactive materials. Test results (Fronczyk 2008, Katzenbach et al. 2008) provide a proposal that the application of appropriate technologies for PRB fulfillment with zeolite and zeolitesand mixtures does not cause increased subsoil softening. As specified by Fronczyk (2008) and Katzenbach et al. (2008), the compressibility and strength characteristics (Tab. 1) may be used in the design of the PRB with zeolite (ZS) and zeolite-sand mixtures with 80 -percentage of zeolite in the mixtures (ZS80). the value of the pollutant concentration from outflow $\left(\mathrm{C}_{\mathrm{K}}\right)$ to the concentration of the substance from inflow to the gates $\left(C_{D}\right)$ is required. In the qualification tests it is recommended to carry out batch tests of the sorption capacity of reactive materials (according to EPA, 1992) with application of groundwater taken from the polluted site. An assessment of the reactive material should be made based on calculations of the time of proper functioning of the barriers, taking into account local hydrogeological conditions (velocity of groundwater flow $\mathrm{v}_{\mathrm{a}}$, concentration of the substance in groundwater $\mathrm{C}_{\mathrm{D}}$ ), and environmental requirements (required concentrations

TABLE 1 . Strength and compressibility parameters of ZS and ZS80

\begin{tabular}{|l|c|c|c|}
\hline Parameter & Unit & ZS & ZS80 \\
\hline $\begin{array}{l}\text { Oedometer compressibility modulus } \boldsymbol{M} \\
\text { (for stress range of 0.10-0.45 MPa) }\end{array}$ & $\mathrm{MPa}$ & 26.9 & 42.8 \\
\hline Angle of internal friction $\boldsymbol{\varphi}$ & $\circ$ & 44 & 44 \\
\hline Cohesion $\boldsymbol{c}^{\prime}$ & $\mathrm{kPa}$ & 28 & 17 \\
\hline
\end{tabular}

\section{SORPTION CRITERIA}

Evaluation of zeolites or zeolite-sand mixtures used to fill gates in the PRB with regard to sorption capacity should be made taking into account the characteristics of the materials and the physical-chemical properties of contaminated groundwater (quantitative and qualitative chemical composition, $\mathrm{pH}$ and redox potential). For materials, in which sorption is the main retention mechanism of groundwater contaminants, the maximum sorption capacity $\mathrm{C}_{a, \max }$ should be taken into account. In general, it can be assumed that the sorption capacity of materials should be higher when a lower ratio of after treatment $\mathrm{C}_{\mathrm{K}}$, usually adopted in accordance with the limit concentrations of groundwater purity grade (Polish decree no 32.284). Application of a reactive material is justified when one of the conditions is fulfilled:

$\mathrm{C}_{\mathrm{a}, \max }>5 \mathrm{mg} / \mathrm{g}$ or $\mathrm{t}_{\mathrm{PRB}}>4$ years

where: $t_{\mathrm{PRB}}$ - estimated "working time" (proper functioning) of PRB. Based on batch tests, Fronczyk (2008) showed that the Slovak zeolite ZS and zeolitesand mixtures ZS80 ( $80 \%$ of zeolite) are materials, which selectively decrease pollution occurring in the leachate of municipal landfills. The most intensive ion-exchange - sorption processes on the surface of studied materials take place 
in inorganic cationic substances $\left(\mathrm{Cu}^{2+}\right.$, $\mathrm{NH}^{4+}, \mathrm{Pb}^{2+}$ ), with lower intensity organic compound dissociated to cations (e.g. methylene blue). Organic compounds that are non-dissociated or dissociated to anions (e.g. phthalic acid, benzene) are not retained by ZS and ZS80 regenerated to sodium.

For the final selection of the reactive material, verification tests (column test, see Fig. 3) with regard to construction technologies of PRB are recommended. This research is carried out to verify the parameters specified on the basis of qualification tests (batch tests). Interpretation of column tests results allows specifying the value of the retardation factor $(\mathrm{R})$, which can be used in the calculations of the $t_{\mathrm{PRB}}$ value from the equation (Czurda et al. 2002):

$\mathrm{t}_{\mathrm{PRB}}=\frac{\mathrm{b} \cdot \mathrm{R}}{\mathrm{v}_{\mathrm{a}}}$

where: $\mathrm{b}$ - barrier width, $\mathrm{R}$ - retardation factor, $\mathrm{v}_{\mathrm{a}}-$ groundwater velocity.

\section{GUIDELINES FOR PRB IN LANDFILL PROTECTION}

The method of PRB with zeolite or zeolite-sand mixtures has a number of advantages, but also limitations resulting from the properties of reactive materials and contaminants as well as processes occurring between pollutants and materials. Results of laboratory tests indicate that the use of PRB with zeolite and zeolite-sand mixtures (ZS80) for groundwater protection in the neighborhood of landfills is justified in the following cases:

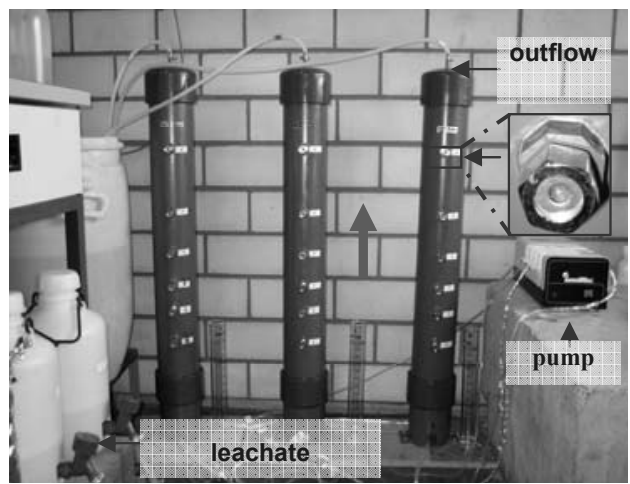

FIGURE 3. Laboratory stand up for column tests

- location of particularly disadvantageous conditions or improperly protected landfill,

- damage of composite liners of landfills (e.g. geomembrane).

The main limitation in the application of ZS80 to PRB near landfills is the limited sorption capacity and selectivity of this material. Among the leachate compounds heavy metals $\left(\mathrm{Cu}^{2+}, \mathrm{Pb}^{2+}\right.$, $\left.\mathrm{Cr}^{3+}\right)$ and $\mathrm{NH}_{4}{ }^{+}, \mathrm{K}^{+}$and $\mathrm{Fe}^{2+} / \mathrm{Fe}^{3+}$ ions are retained, whereas others do not react with the material, or the intensity or duration of these processes are not sufficient to achieve the required concentrations in groundwater (Fronczyk 2008, Katzenbach et al. 2008).

Selection of the reactive material requires analysis of the investigations carried out in accordance with the diagram shown in Figure 4.

\section{CONCLUSIONS}

In the selection of reactive materials for PRB the hydraulic, sorption, as well as mechanical criteria should be taken into account. These criteria should be analyzed based on the results of 


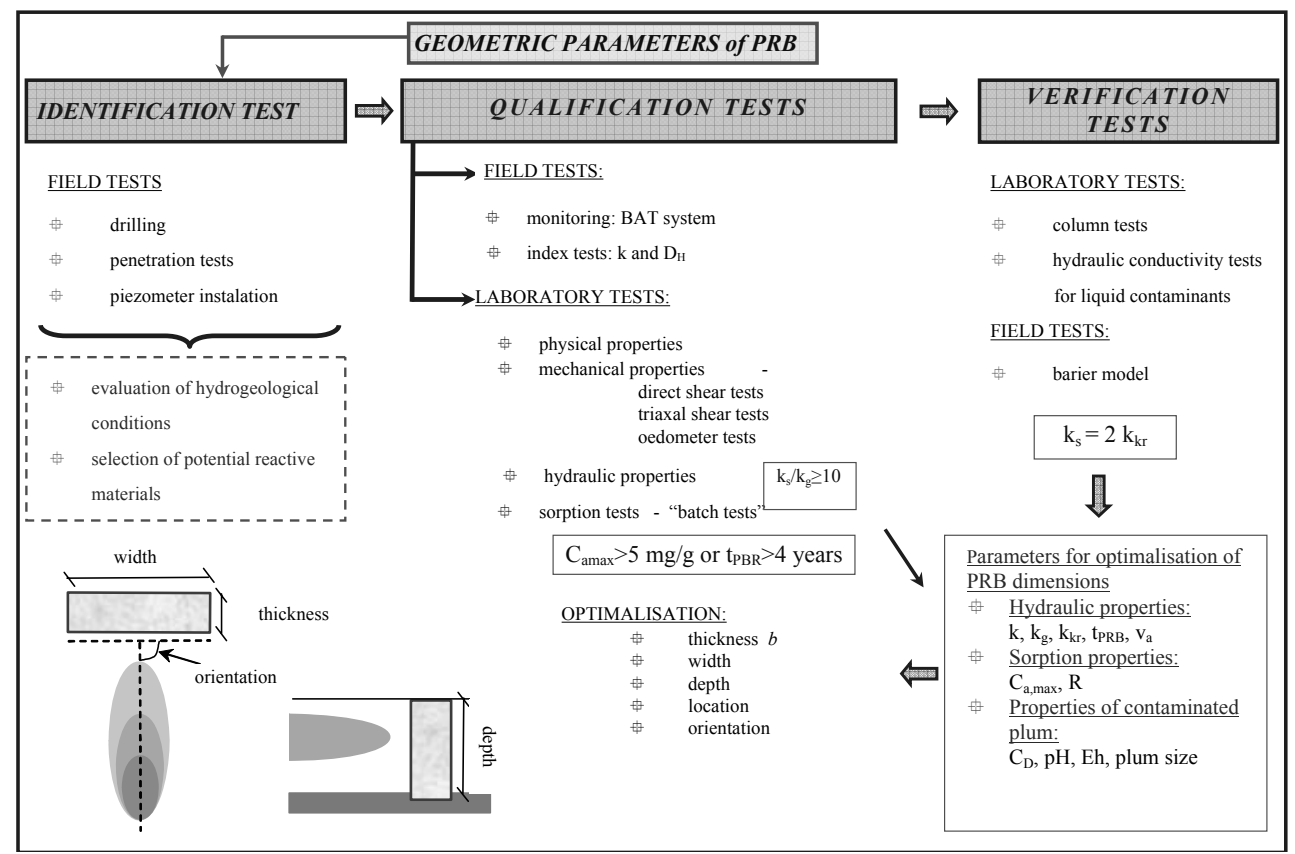

FIGURE 4. Diagram for determining the geometrical parameters of PRB

investigations carried out in three stages. Qualification tests permit assessing the properties of reactive materials on the basis of the maximum sorption capacity $\mathrm{C}_{\mathrm{a}, \max }$, hydraulic conductivity, as well as compressibility and strength parameters.

The main limitation of PRB application with ZS and ZS80 is the inability to retain the entire spectrum of contaminants that may potentially be present in the landfill. Specific questions arise when considering the retention of pollutants such as organic compounds and anionic substances.

PRB is an inexpensive method and doesnotconvey technological difficulties. The effectiveness of the method depends on the properties of reactive materials. In the case of zeolites and zeolite-sand mixtures the PRB method should apply the principles given in this study.
Acknowledgments: This research was supported by Grant no. 2P04G 088 29 from the Ministry of Science and Higher Education, Warsaw, Poland.

\section{REFERENCES}

CZURDA K.A., HAUS R., 2002: Reactive barriers with fly ash zeolites for in situ ground water remediation. Applied Clay Science, 21: 13-20.

EPA, 1992: Batch-type procedures for estimating soil adsorption of chemicals. EPA/530SW87006F.

FRONCZYK J., 2008: Zeolite-sand mixtures in permeable reactive barriers in the landfill surroundings. $\mathrm{PhD}$ thesis, Faculty of Engineering and Environmental Science WULS.

GAVASCAR A., GUPTA N., SASS B., JANOSY R., HICKS J., 2000: Design guidance for application of permeable 
reactive barriers for groundwater remediation. Battelle.

KATZENBACH R., FRONCZYK J., GARBULEWSKI K., 2008: Evaluation of zeolite-sand mixtures as a reactive material towards landfill leachate. 11th Baltic Sea Geotechnical Conference. 15.-18.09.2008, Gdańsk.

Polish decree no 32, 284: Rozporządzenie Ministra Środowiska z dnia 11 lutego 2004 r. w sprawieklasyfikacjidla prezentowania stanu wód powierzchniowych i podziemnych, sposobu prowadzenia monitoringu oraz sposobu interpretacji wyników i prezentacji stanu tych wód.

ROEHL K.E., MEGGYES T., SIMON F.G., STEWART D.I., 2005: Long-term performance of permeable reactive barriers. Elsevier B.V.

SUPONIK T., 2004: Optymalizacja parametrów bariery remediacyjnej dla zanieczyszczonych wód gruntowych obszaru składowisk odpadów. PhD thesis, Faculty of Mining and Geology, Sląsk University, of Technology, Gliwice.

VANGULCK J.F., ROWE R.K., 2004: Influence of landfill leachate suspended solids on clog (biorock) formation. Waste Management, 24: 723-738.
Streszczenie: Kryteria doboru materiałów do wykonania przepuszczalnych barier reaktywnych (PBR) w rejonie skladowisk odpadów. W artykule przedstawiono kryteria, które są konieczne do wybrania, zależnie od lokalnych warunków środowiskowych i geologicznych, odpowiedniego materiału do wykonania PBR w rejonie składowisk odpadów. Kryteria doboru materiałów obejmują trzy aspekty: hydrauliczny, sorpcyjny i mechaniczny (właściwości wytrzymałościowe i odkształceniowe). Kryteria hydrauliczne i sorpcyjne są równoważne i uzupełniające się przy wyborze odpowiedniego materiału reaktywnego. Optymalnym materiałem jest ten, który równocześnie spełnia oba kryteria. Kryterium trzecie - mechaniczne - powinno być wzięte pod uwagę w projektowaniu technologii i określeniu niezawodności PBR.

MS. received May 2009

\author{
Authors' address: \\ Joanna Fronczyk \\ Kazimierz Garbulewski \\ Katedra Geoinżynierii \\ Wydział Inżynierii i Kształtowania Środowiska, \\ SGGW \\ 02-776 Warszawa, Nowoursynowska 159, \\ Poland
}

